\title{
Effect of Glass Waste Powder on the Compressive Strength and Permeation Properties of Concrete Containing Portland Cement and Sawdust Ash
}

\author{
Samuel Olufemi FOLAGBADE ${ }^{*} \quad$ Alabi Sheriff OLATUNJI ${ }^{2}$ \\ 1.Department of Building, Obafemi Awolowo University, Ile-Ife 0220005, Nigeria \\ 2.Platform Concept, Iwo, Nigeria
}

\begin{abstract}
The paper investigated the effect of Glass Waste Powder (GWP), as a ternary cement component on the compressive strength and permeation resistance of Portland cement (PC) and sawdust ash (SDA) blended cement concrete. Compressive strengths up to 28 days and void content and initial surface absorption after 10 minutes (ISAT-10) up to 90 days at the total replacement levels of up to $30 \%$ were determined and compared with the values obtained for conventional concrete. Seven concrete mix combinations were examined at the water/cement (w/c) ratios of $0.35,0.50$ and 0.65 and at 28 -day strengths of $35-40 \mathrm{~N} / \mathrm{mm}^{2}$. At the same w/c ratios, compressive strength decreased and void content and ISAT-10 increased with increasing content of SDA and GWP. A unit replacement of $\mathrm{PC}$ with SDA reduced strength by $1.06 \%$ while a unit replacement of SDA with GWP, as a ternary cement component, increased strength by $1.64 \%$. Similarly, a unit of SDA increased void content and ISAT-10 by 0.95 and $1.01 \%$ respectively while a unit of GWP as a ternary cement component reduced void content and ISAT-10 by 0.84 and $0.94 \%$ respectively. At same strengths, all the binary and ternary cement concretes possess higher resistance to permeation than the $100 \% \mathrm{PC}$ concrete. At equal performance level, the ternary cement concretes possess higher permeation resistance than the binary cement concretes. The paper concluded that GWP, as a ternary cement component, improved the strength and permeation resistance of SDA binary cement concrete.
\end{abstract}

Keywords: absorption, compressive strength, concrete, glass waste powder, permeation, sawdust powder

DOI: $10.7176 / \mathrm{CER} / 12-4-05$

Publication date: April $30^{\text {th }} 2020$

\section{Introduction}

The reports submitted by the Intergovernmental Panel on Climate Change have shown that increasing level of emissions into the atmosphere has a devastating effect on the environment. Hence, in order to reduce the consumption of Portland cement (PC) and reduce the emissions linked with its production, the use of byproducts of industrial wastes such as silica fume, fly ash, metakaolin and ground granulated blast furnace slag as supplementary cementitious materials to partly replace the Portland cement content of concrete has been found worthwhile (BS EN 197- 1, 2000; BS EN 206- 1, 2000; BS 8500- 1, 2006, \& BS 8500- 2, 2006). Supplementary Cementitious Materials (SCMs) undergo pozzolanic reaction and are characterized by low early-age performance which could be improved if appropriately mixed in the right proportion as binary or ternary blends with Portland cement (Wild et al., 1996; Thomas et al., 1999; Bai et al., 2000; Hassan et al., 2000; Poon et al., 2006; Radlinski \& Olek, 2012; Folagbade, 2014; Folagbade \& Newlands, 2014a; Folagbade, 2017). For example, due to their higher silica content and fineness, the addition of small quantities of metakaolin and silica fume as ternary cement components would improve the performance of fly ash binary cements at early ages (Folagbade, 2014; Folagbade \& Newlands, 2014a; Folagbade, 2017).

Various studies have also supported, among others, the use of by-products of agricultural wastes like rice husk ash (Zhang \& Malhotra, 1996; Coutinho, 2003 \& Nehdi et al., 2003), corncob ash (Adesanya \& Raheem, 2009, 2010; Akinwumi \& Aidomojie, 2015), cassava peels ash (Ogunbode \& Akanmu, 2012) and sawdust ash (Udoeyo \& Dashibil, 2002; Elinwa \& Ejeh, 2004; Raheem et al., 2017) as possible SCMs. The studies also concluded that these by-products would reduce concrete strength at early ages due to delayed pozzolanic reaction. In order to support its use, the focus of this paper is to provide information on how the strength and durability performance of sawdust ash concrete could be improved.

Sawdust is an agricultural waste found in great quantity in Nigeria and many countries of the world. Despite being used domestically, the level of sawdust waste is still high (Oluoti et al., 2014). Sawdust ash (calcined sawdust) would reduce concrete performance at early ages and its continued pozzolanic reaction with increasing curing age would improve its strength and durability performance at later ages (Obilade, 2014; Folagbade \& Aluko, 2019). Also, if blended in the right proportion, SDA binary cement concrete would have good strength properties, dense microstructure and improved resistance to permeation (Folagbade \& Aluko, 2019). Hence, in order to ensure good results, Folagbade \& Aluko (2019) suggested an SDA content of not more than $20 \%$ in concrete. Furthermore, Elinwa et al. (2005) suggested that the performance of sawdust ash could be improved by 
adding small quantities of SCMs with higher silica content. With this improvement, it is also possible that SDA content of more than $20 \%$ could be used in concrete to further reduce the Portland cement content and increase the environmental compatibility of concrete.

Glass powder, a good source of silica, will undergo pozzolanic reaction to produce strong, durable, cheap and environmentally compatible concrete when used at $20-30 \%$ content to partly replace Portland cement (Shayan \& Xu, 2006; Maraghechi et al., 2014; Rashed, 2014); Sadiqul Islam et al., 2017). However, for an optimum result, a replacement level of $10 \%$ glass powder has been suggested (Sadiqul et al., 2017). Also, in order to prevent concrete from cracking due to alkali-silica reaction concrete, the particle size of glass powder should not exceed $300 \mu \mathrm{m}$ (Ke et al., 2018). From the foregoing, the blending of SDA and GWP could permit the use of higher contents of SCMs and make the blended cement concrete more economic and environmentally compatible than the conventional PC concrete at equal strength and durability levels. This is because the comparatively lower embodied energy of SDA and GWP than that of Portland cement clinker would make the ternary blended cement to be cheaper and more environmentally compatible than PC.

A good concrete is expected to be strong and durable. Also, while the strength of concrete is assessed with the aid of its compressive strength, its durability in aggressive media will depend on its permeation resistance. Hence, this paper investigated the strength development, void content and initial surface absorption (ISAT) of the ternary cement concrete. This is because while void content would measure the porosity, ISAT would measure the water absorption capacity of the surface zone of concrete which could be used to assess its resistance to permeation and its ability to protect the embedded reinforcing steel against corrosion. Hence, the results will provide more information on the suitability of the ternary cement concrete as a construction material.

\section{Experimental Materials and Methods}

The cements used in the experiments are ordinary Portland cement (PC), sawdust ash (SDA) calcined at at a temperature of $500^{\circ} \mathrm{C}$ and glass waste powder (GWP) ground in a ball mill. The oxide compositions of PC, SDA and GWP are given in Table 1 and the grading curves are presented in Figure 1. SDA was used to replace PC at 20 and $30 \%$ contents to form binary cement combinations. GWP was used to replace the SDA contents of the binary cements at 5 and $10 \%$ contents to form the ternary cement combinations. The content of GWP was limited to $10 \%$ for optimum result (Sadiqul Islam et al., 2017) and the particle size was limited to a maximum of $300 \mu \mathrm{m}$ to mitigate alkali-silica reaction (Ke et al., 2018). The aggregates used are sand (with a specific gravity of 2.63) as fine aggregates and granite (with a specific gravity of 2.80) as coarse aggregates. Concrete design was based on the Building Research Establishment Design Guide (Teychenne et al., 1997) and investigated at the water/cement ratios of $0.35,0.50$ and $0.65 \mathrm{using}$ a free water content of $210 \mathrm{~kg} / \mathrm{m}^{3}$. Mapefluid N200, a superplasticiser conforming to BS EN 934-2 (2009), was used during mixing to obtain a consistence class of S2 characterised by a slump of between 50 and $90 \mathrm{~mm}$ (BS EN 206- 1, 2000).

Table 1: Oxide compositions of Portland cement, sawdust ash and glass waste powder

\begin{tabular}{llll}
\hline Elemental Oxide $(\%)$ & $\mathrm{PC}$ & $\mathrm{SDA}$ & $\mathrm{GWP}$ \\
\hline $\mathrm{SiO}_{2}$ & 20.36 & 68.71 & 70.03 \\
$\mathrm{Al}_{2} \mathrm{O}_{3}$ & 5.67 & 4.54 & 2.16 \\
$\mathrm{Fe}_{2} \mathrm{O}_{3}$ & 2.92 & 2.05 & 0.71 \\
$\mathrm{CaO}$ & 63.17 & 9.48 & 11.51 \\
$\mathrm{MgO}$ & 1.88 & 4.13 & 2.76 \\
$\mathrm{SO}$ & 2.86 & 1.07 & 0.12 \\
$\mathrm{~K}_{2} \mathrm{O}$ & 0.78 & 2.45 & 0.66 \\
$\mathrm{Na}_{2} \mathrm{O}$ & 0.24 & 0.06 & 11.42 \\
$\mathrm{P}_{2} \mathrm{O}_{5}$ & - & - & 0.05 \\
$\mathrm{TiO}_{2}$ & - & - & 0.09 \\
$\mathrm{CaCO}_{3}$ & - & 4.80 & - \\
$\mathrm{Cr}_{2} \mathrm{O}_{3}$ & - & - & 0.11 \\
$\mathrm{LOI}^{\mathrm{SiO}}+\mathrm{Al}_{2} \mathrm{O}_{3}+\mathrm{Fe}_{2} \mathrm{O}_{3}$ & 2.12 & 2.71 & 0.38 \\
\hline $\mathrm{SiO}_{2}$ & & 75.30 & 72.90 \\
\hline
\end{tabular}




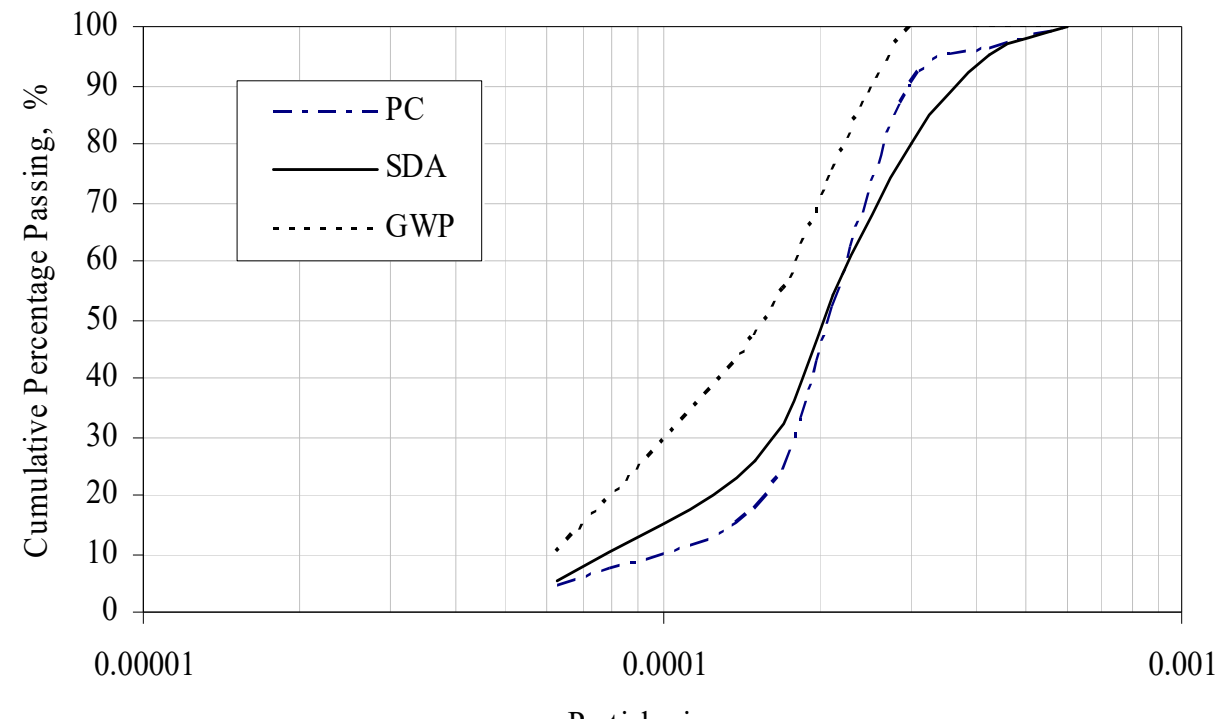

Particle size, $m$

Figure 1: Grading curves of cements

Concrete was prepared to standard (BS EN 12390-2, 2000), placed and stored under polythene for about a day and demoulded and cured in water. Compressive strength, void content and initial surface absorption tests were performed on the hardened concrete specimens. Compressive strength was determined to standard (BS EN 12390- 3, 2002) using $100 \mathrm{~mm}$ cubes at the curing ages of 7, 14, 21 and 28 days. Void content was determined at the curing ages of 28,60 and 90 days in line with ASTM C642 (2006) using Equation 1. This involved determining mass of specimen oven-dried to constant mass at $105 \pm 5^{\circ} \mathrm{C}(\mathrm{A})$, mass of specimen after immersion to constant mass in water and boiling (B) and apparent mass of specimen after immersion, boiling and suspension in water $(\mathrm{C})$.

Void content $(\%)=\frac{B-A}{B-C} * 100$

Initial surface absorption after 10 minutes (ISAT-10) was determined at 28, 60 and 90 days in line with standard (BS 1881- 208, 1996) using $150 \mathrm{~mm}$ concrete cubes dried to constant mass at a temperature of $105 \pm 5^{\circ} \mathrm{C}$. This is because ISAT-10 is sufficient for assessing the effect of absorption due to driving rain on the surface of concrete (BS 1881-208, 1996). After oven-drying and cooling, the specimens were exposed to a pressure of 200 $\mathrm{mm}$ head of water (Figure 2). Tap was turned off after 10 minutes of contact with water to stop the applied pressure and ISAT-10 was obtained as the product of scaled divisions moved by water in a minute along the capillary tube and the calibration factor of the capillary tube (Equation 2).

ISAT $-10=\mathrm{SD} \times \mathrm{CF}$

ISAT-10 $=$ Initial surface absorption of concrete 10 minutes after water first touched its surface.

$\mathrm{SD}=$ Scaled divisions moved by water, in a minute, after tap was turned off.

$\mathrm{CF}=$ Calibration factor of capillary tube determined to standard (BS 1881-208, 1996). 


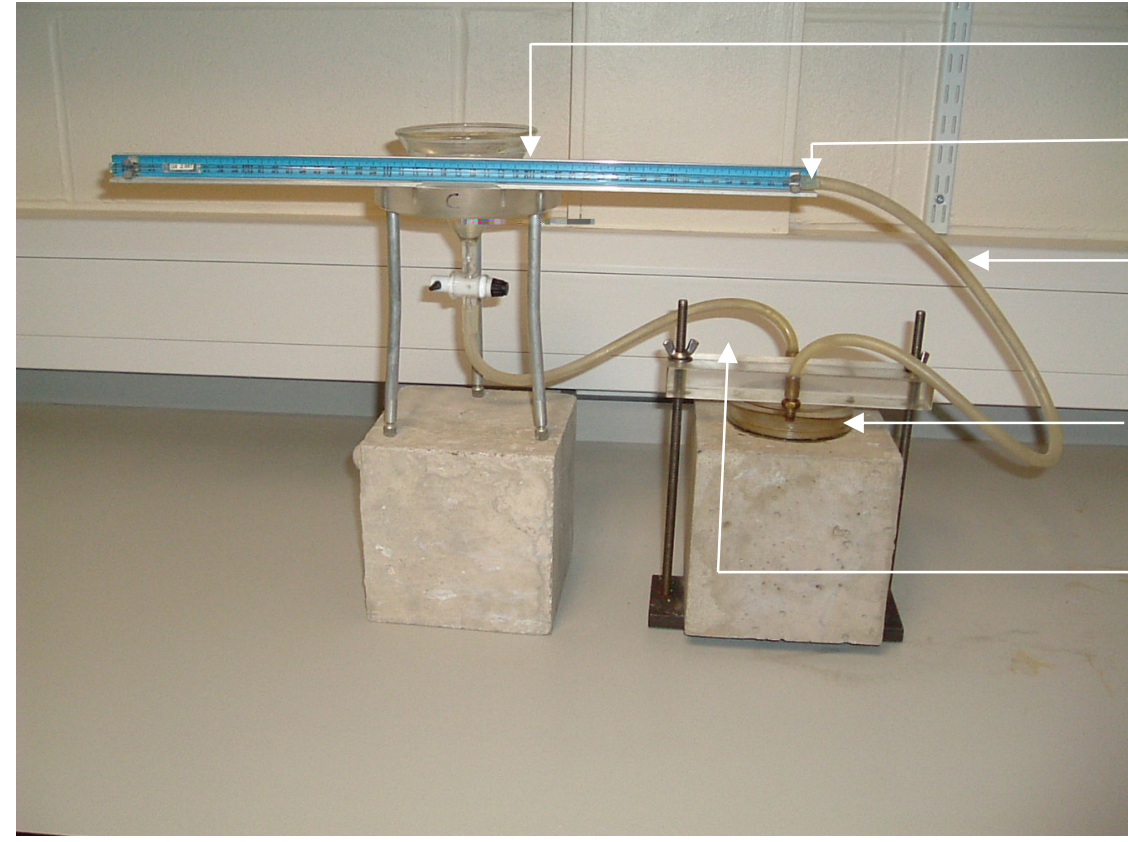

Figure 2: ISAT installation
$200 \mathrm{~mm}$ head of water

Capillary tube fixed to a

measuring scale

Outlet tube connected to the capillary tube

Water-tight cap clamped to concrete surface

Inlet tube connected to the cap

\section{Results and Discussion}

The results of the compressive strength, void content and initial surface absorption after 10 minutes (ISAT- 10) of concrete at different contents of sawdust ash (SDA) and glass waste powder (GWP), water/cement ratios and 0.65 and ages up to 28 days are presented and compared. Compressive strength was compared at equal water/cement ratios while void content and ISAT- 10 were compared at equal water/cement ratios, equal 28-day strengths and equal performance levels.

\subsection{Compressive Strength of Concrete}

The compressive strength of concrete at different contents of sawdust ash (SDA) and glass waste powder (GWP), water/cement ratios and 0.65 and ages up to 28 days are presented in Table 2. In line with previous studies, compressive strength increased with increasing curing age (due to the formation of more strength enhancing hydration products) and reduced with increasing water/cement ratio (due to dilution effect caused by reduction in the quantity of cement). Hence, the strength factors of the cement combination concretes increased with increasing curing age. Also, the reduction in the disparities between the strength factors of the cement combination concretes and that of the 100PC concrete, with increasing curing age, further confirms the pozzolanicity of SDA and GWP and the ability of the supplementary cementitious materials to support later-age strength development. 
Table 2: Compressive strengths of concretes

\begin{tabular}{|c|c|c|c|c|c|c|c|c|c|c|c|}
\hline \multirow{3}{*}{ Mix } & \multirow{3}{*}{$\mathrm{w} / \mathrm{c}$} & \multicolumn{4}{|c|}{ Compressive strength, $\mathrm{N} / \mathrm{mm}^{2}$} & \multicolumn{6}{|c|}{ Strength factor, $\%$} \\
\hline & & \multirow[t]{2}{*}{$\mathrm{d} 7$} & \multirow[t]{2}{*}{$\mathrm{d} 14$} & \multirow[t]{2}{*}{$\mathrm{d} 21$} & \multirow[t]{2}{*}{$\mathrm{d} 28$} & \multirow[t]{2}{*}{$\mathrm{d} 7$} & \multirow[t]{2}{*}{ d14 } & \multirow[t]{2}{*}{$\mathrm{d} 21$} & \multirow[t]{2}{*}{$\mathrm{d} 28$} & \multicolumn{2}{|c|}{ Average } \\
\hline & & & & & & & & & & $\mathrm{d} 28$ & Red $^{\mathrm{a}}$ \\
\hline \multirow{3}{*}{$100 \mathrm{PC}$} & 0.35 & 30.0 & 39.0 & 45.0 & 51.0 & 100 & 100 & 100 & 100 & \multirow{3}{*}{100} & \multirow{3}{*}{-} \\
\hline & 0.50 & 23.0 & 31.0 & 36.5 & 41.0 & 100 & 100 & 100 & 100 & & \\
\hline & 0.65 & 19.5 & 28.5 & 33.0 & 37.0 & 100 & 100 & 100 & 100 & & \\
\hline $80 \mathrm{PC}$ & 0.35 & 22.0 & 29.5 & 35.0 & 40.5 & 73.3 & 75.6 & 77.7 & 79.4 & \multirow{3}{*}{78.6} & \multirow{3}{*}{21.4} \\
\hline \multirow[t]{2}{*}{+20 SDA } & 0.50 & 17.0 & 23.5 & 28.0 & 32.0 & 73.9 & 75.8 & 76.7 & 78.0 & & \\
\hline & 0.65 & 14.5 & 21.5 & 25.5 & 29.0 & 74.4 & 75.4 & 77.3 & 78.4 & & \\
\hline $80 \mathrm{PC}$ & 0.35 & 24.5 & 32.5 & 39.0 & 45.0 & 81.7 & 83.3 & 86.7 & 88.2 & \multirow{3}{*}{87.9} & \multirow{3}{*}{12.1} \\
\hline$+15 \mathrm{SDA}$ & 0.50 & 19.0 & 26.0 & 31.5 & 36.0 & 82.6 & 83.9 & 86.3 & 87.8 & & \\
\hline$+5 \mathrm{GWP}$ & 0.65 & 16.0 & 24.0 & 28.5 & 32.5 & 82.1 & 84.2 & 86.4 & 87.8 & & \\
\hline $80 \mathrm{PC}$ & 0.35 & 26.5 & 35.0 & 41.0 & 47.5 & 88.3 & 89.7 & 91.1 & 93.1 & & \\
\hline$+10 \mathrm{SDA}$ & 0.50 & 20.5 & 28.0 & 33.5 & 38.5 & 89.1 & 90.3 & 91.8 & 93.9 & 93.4 & 6.6 \\
\hline +10GWP & 0.65 & 17.5 & 26.0 & 30.5 & 34.5 & 89.7 & 91.2 & 92.4 & 93.2 & & \\
\hline $70 \mathrm{PC}$ & 0.35 & 19.0 & 25.5 & 30.0 & 35.0 & 63.3 & 65.4 & 66.7 & 68.6 & \multirow{3}{*}{68.6} & \multirow{3}{*}{31.4} \\
\hline \multirow[t]{2}{*}{$+30 \mathrm{SDA}$} & 0.50 & 14.5 & 20.0 & 24.5 & 28.0 & 63.0 & 64.5 & 67.1 & 68.3 & & \\
\hline & 0.65 & 12.5 & 18.5 & 22.0 & 25.5 & 64.1 & 64.9 & 66.7 & 68.9 & & \\
\hline $70 \mathrm{PC}$ & 0.35 & 21.5 & 29.0 & 34.0 & 39.0 & 71.7 & 74.4 & 75.6 & 76.5 & \multirow{3}{*}{76.8} & \multirow{3}{*}{23.2} \\
\hline$+25 \mathrm{SDA}$ & 0.50 & 16.5 & 23.0 & 27.5 & 31.5 & 71.7 & 74.2 & 75.3 & 76.8 & & \\
\hline$+5 \mathrm{GWP}$ & 0.65 & 14.0 & 21.0 & 25.0 & 28.5 & 71.8 & 73.7 & 75.8 & 77.0 & & \\
\hline $70 \mathrm{PC}$ & 0.35 & 23.0 & 31.5 & 37.0 & 43.0 & 76.7 & 80.8 & 82.2 & 84.3 & \multirow{3}{*}{84.1} & \multirow{3}{*}{15.9} \\
\hline$+20 \mathrm{SDA}$ & 0.50 & 17.5 & 25.0 & 30.0 & 34.5 & 76.1 & 80.6 & 82.2 & 84.1 & & \\
\hline +10GWP & 0.65 & 15.0 & 23.0 & 27.0 & 31.0 & 76.9 & 80.7 & 81.8 & 83.8 & & \\
\hline
\end{tabular}

The partial replacement of PC with SDA resulted in concrete with reduced compressive strength. This observation is supported by Raheem et al. (2017) and Folagbade (2018). Compared with 100PC concrete, the 28 day compressive strength reduced with increase in the content of SDA, as a binary cement component, by 21.4 and $31.4 \%$ at 20 and $30 \%$ contents of SDA; resulting in strength reductions of 1.07 and $1.05 \%$ respectively (with a mean of $1.06 \%$ ) for a unit replacement of PC with SDA. Also, compared with the SDA binary cement concretes, the addition of 5\% GWP as a ternary cement component increased the 28 day strength by $9.3 \%(21.4$ minus 12.1) and 8.2\% (31.4 minus 23.2) at the total replacement levels of 20 and $30 \%$ respectively. These resulted, respectively, in strength increases of 1.86 and $1.64 \%$ (with a mean of $1.75 \%$ ) for a unit replacement of SDA with GWP. Similarly, the addition of $10 \%$ GWP as a ternary cement component resulted in strength increases of $14.8 \%$ (21.4 minus 6.6) and 15.5\% (31.4 minus 15.9) at the total replacement levels of 20 and $30 \%$ respectively. These also resulted, respectively, in strength increases of 1.48 and $1.55 \%$ (with an average of $1.52 \%$ ) for a unit replacement of SDA with GWP. Combining the results at the two levels of total replacement, a unit replacement of SDA with GWP resulted in strength increases of 1.52 and $1.75 \%$ (with an average of $1.64 \%$ ). Hence, GWP as a ternary cement component could be used to improve the strength development of SDA binary cement concrete. This result is also supported by Khatib et al. (2012).

\subsection{Void Content and initial Surface Absorption of Concrete at different Water/Cement Ratios}

Figures 3-8 present the void content and initial surface absorption of concrete at different curing ages and water/cement ratios and dfferent contents of SDA and GWP. As expected, the Figures show that void content and initial surface absorption of concrete reduced with curing age as a result of refinement of pore structure by hydration products; and increased with increase in water/cement ratio due to reduction in the content of the cements. 

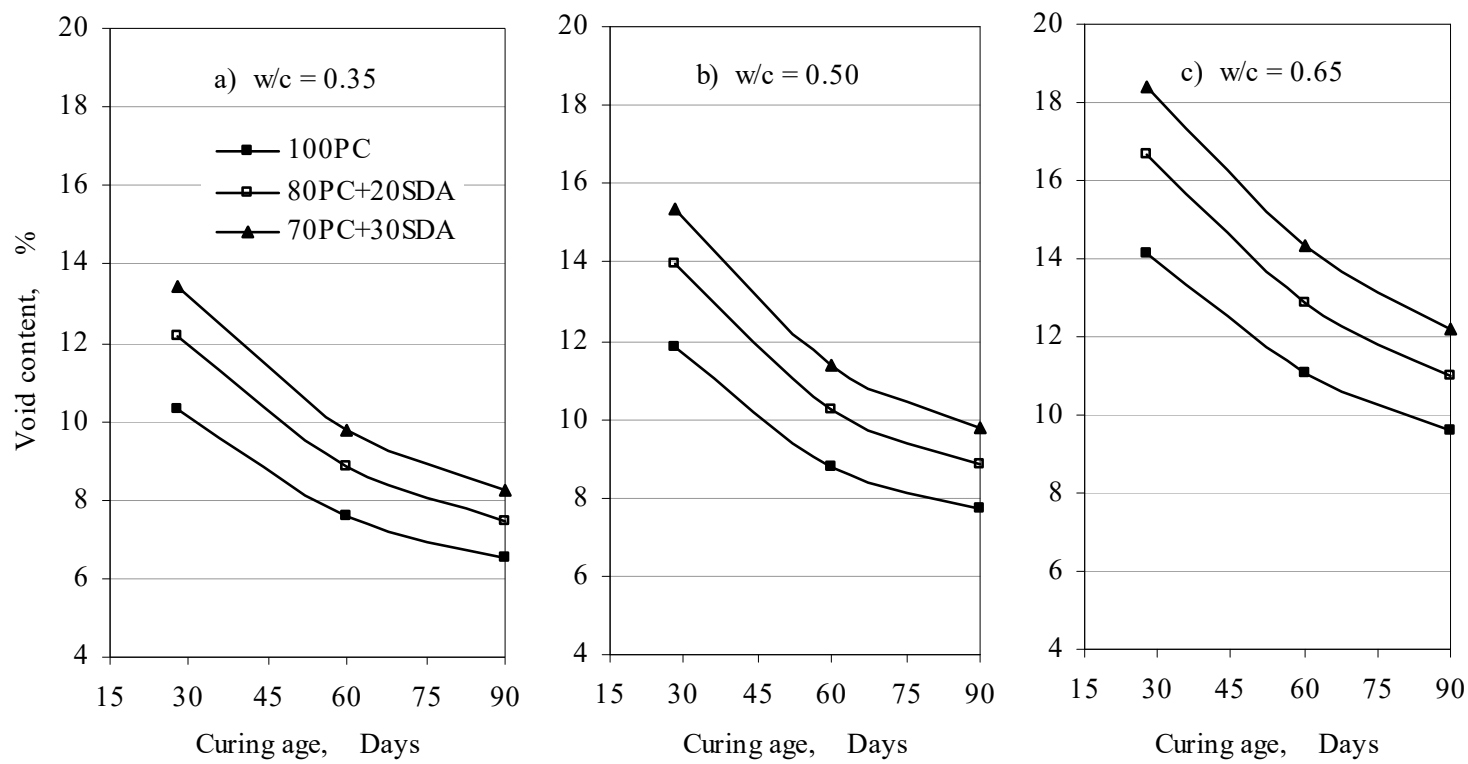

Figure 3: Void content of PC and SDA blended cement concretes
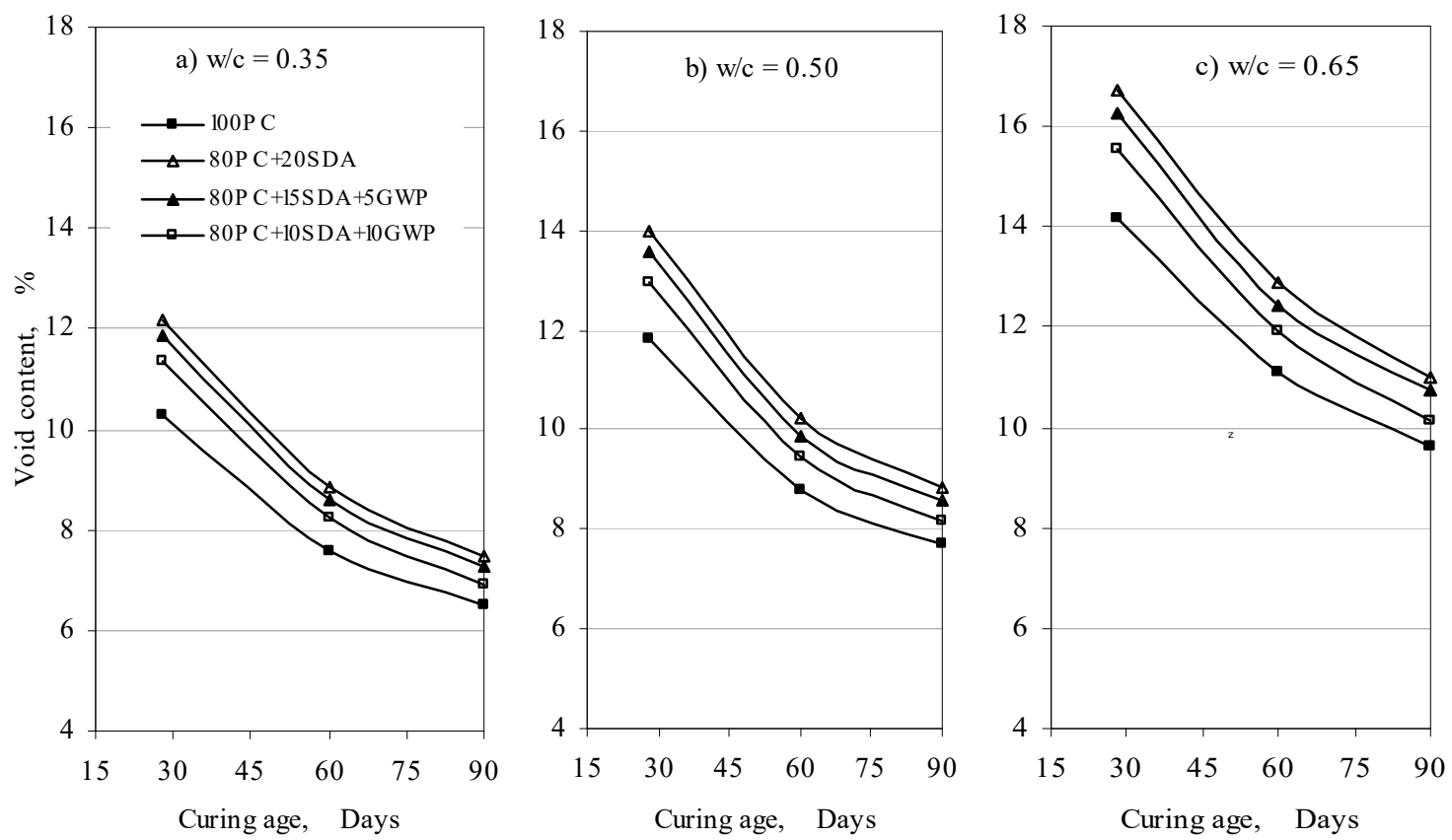

Figure 4: Void content of concrete at $20 \%$ total replacement level 

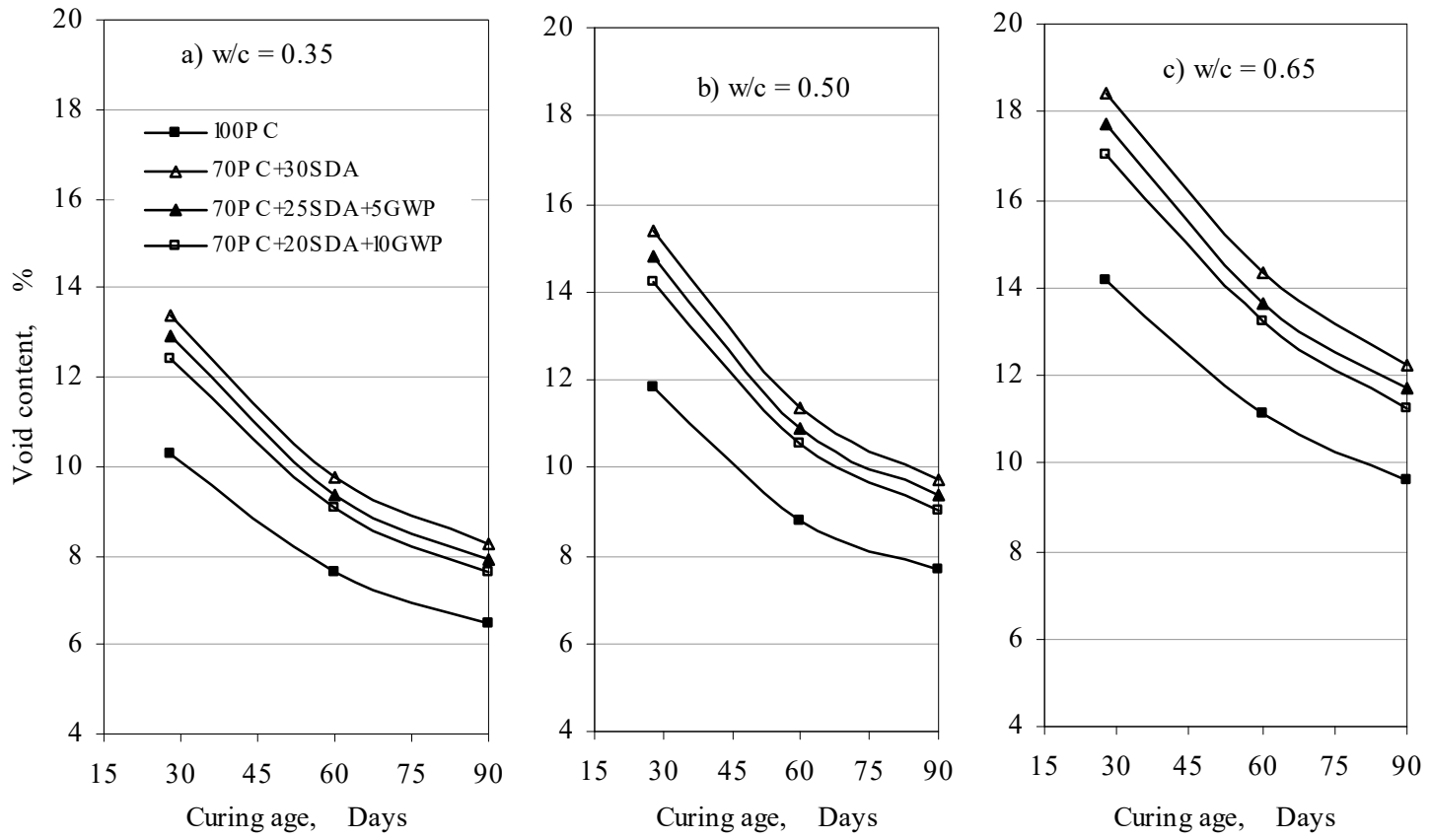

Figure 5: Void content of concrete at $30 \%$ total replacement level
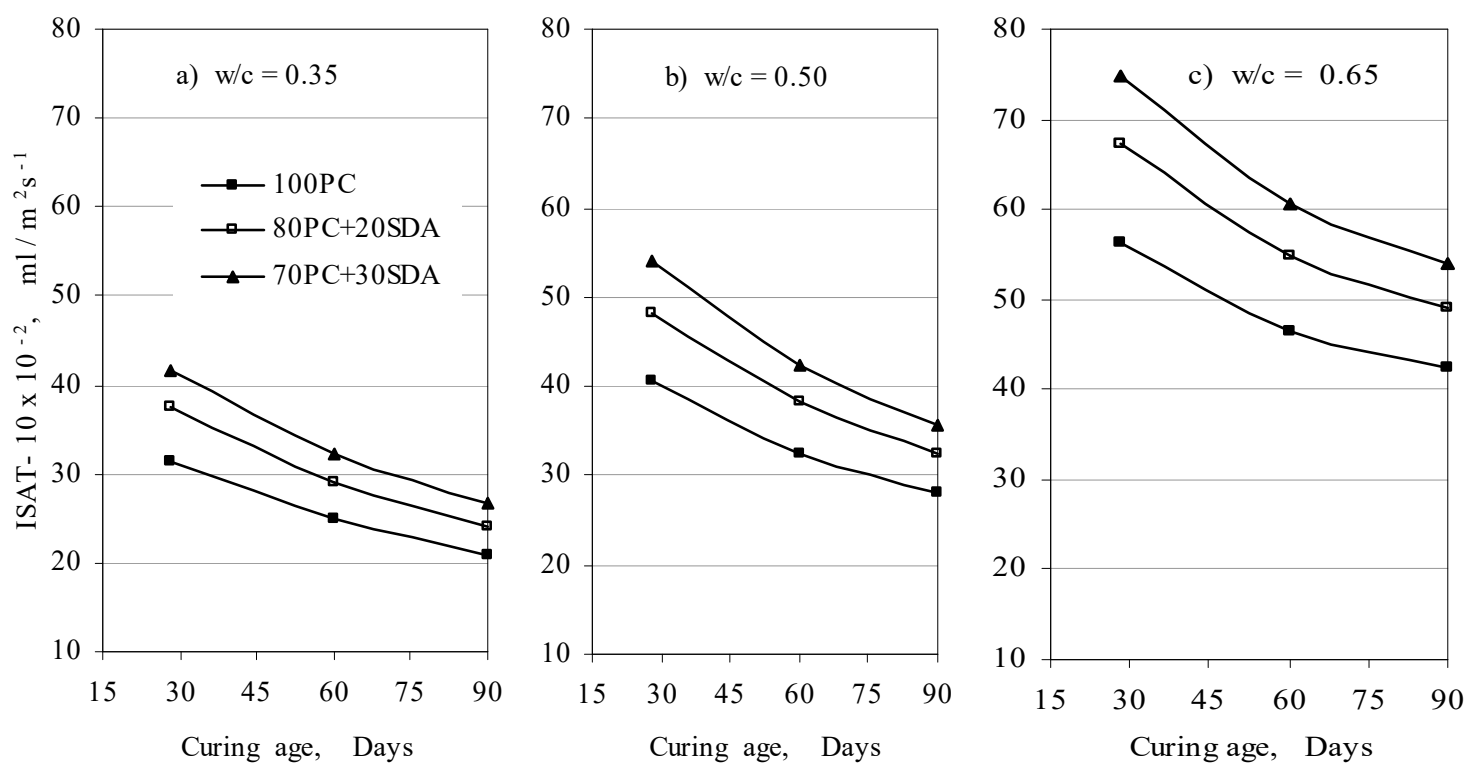

Figure 6: Initial surface absorption of PC and SDA blended cement concretes 

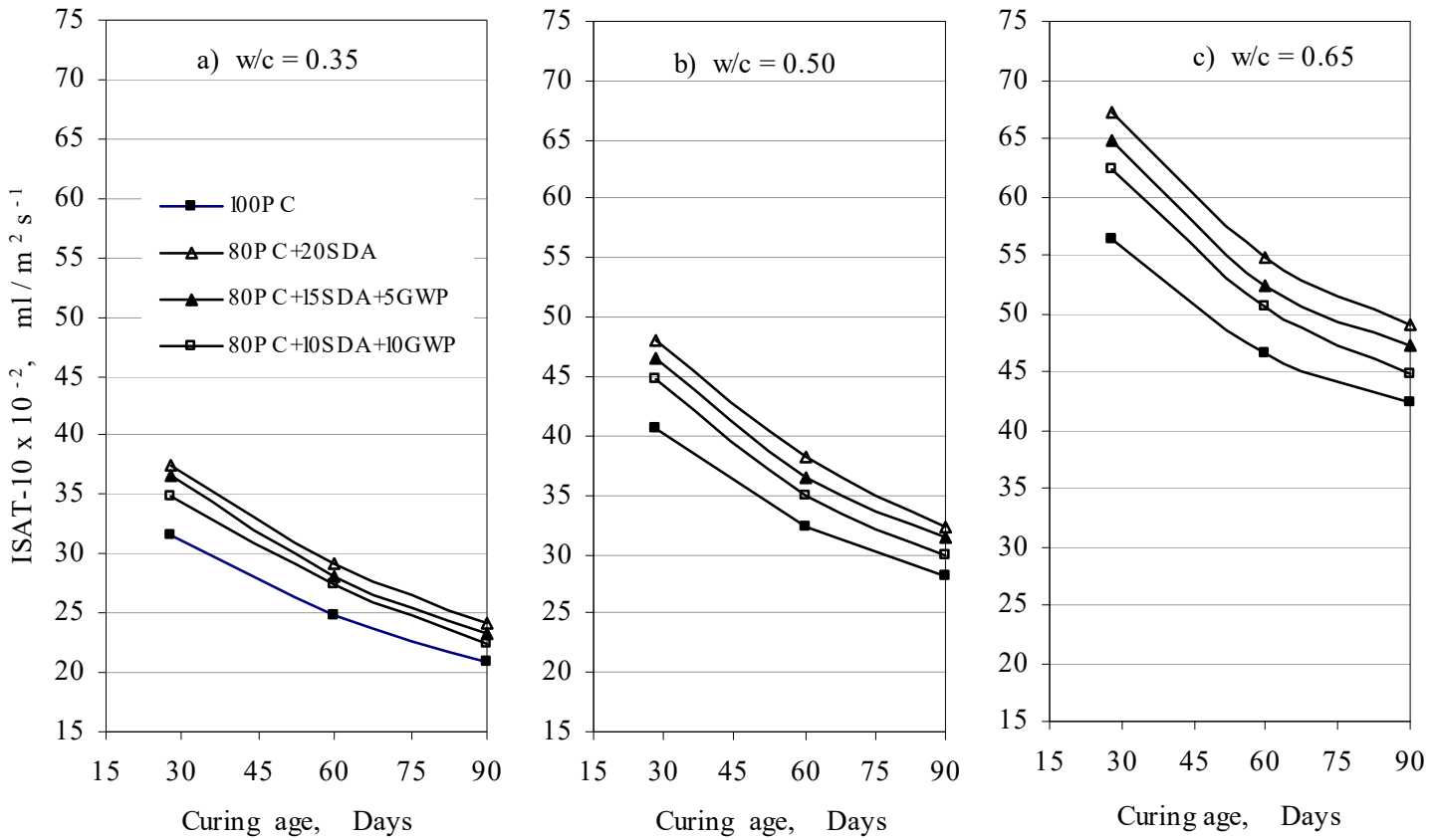

Figure 7: ISAT-10 of concrete at $20 \%$ total replacement level
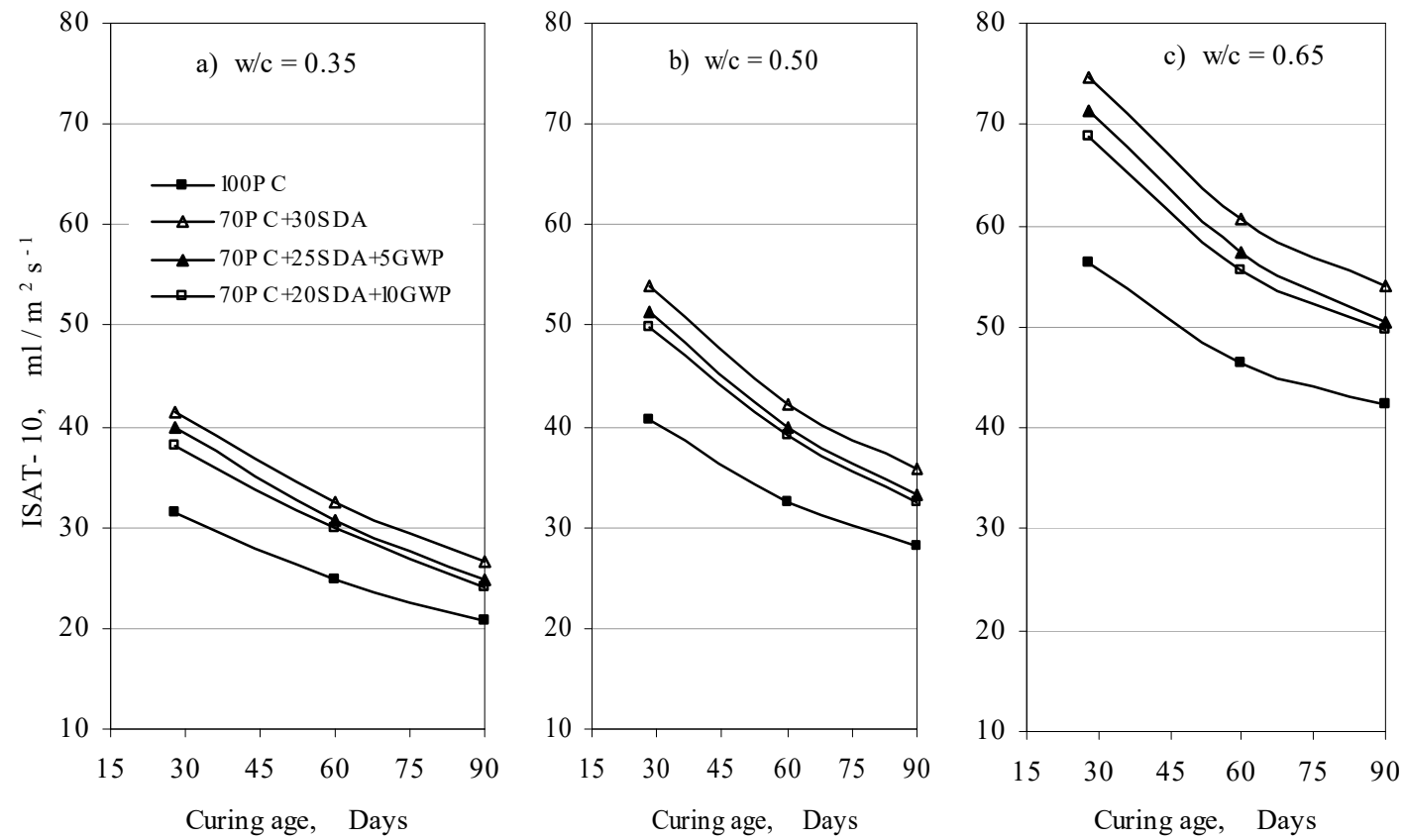

Figure 8: ISAT-10 of concrete at $30 \%$ total replacement level

The Figures also show that, at equal ages and water/cement ratios, void content and initial surface absorption increased with increase in the content of SDA as a binary cement component and reduced with increase in the content of WGP as a ternary cement component. According to Folagbade \& Aluko (2019), the increase in ISAT-10 with increase in SDA content would be caused by the decrease in the content of Portland cement, $\mathrm{Ca}(\mathrm{OH})_{2}$ and pozzolanic reaction of SDA and the consequent reduction in the development of sufficient hydration products and less permeable microstructure. The reduction in void content and initial surface absorption with increase in the content of GWP, as a ternary cement component, would be due to its higher silica $\left(\mathrm{SiO}_{2}\right)$ content resulting in more hydration products (Table 2). This is because silica in glass powder will react with $\mathrm{Ca}(\mathrm{OH})_{2}$ to produce more calcium silicate hydrate gel that would reduce void content (Ke et al., 2018) and therefore reduce the initial surface absorption of the ternary cement concrete.

Table 3 presents the analysis of the 28 -day void content and ISAT-10 of the concretes. The void content factors and the ISAT-10 factors respectively measure the differences between the 28-day void content and ISAT- 
10 of the 100PC concrete and the blended cement concretes at different water/cement ratios. The Table shows that the 28-day void content of concrete increased respectively by 18.0 and $30.1 \%$ at 20 and $30 \%$ contents of SDA resulting in percentages of increase in void content of 0.90 and 1.00 respectively (with a mean of $0.95 \%$ ) for a unit replacement of PC with SDA. With the addition of 5\% GWP, as a ternary cement component, the 28day void content reduced by 2.9 and $4.9 \%$ at the total replacement levels of 20 and $30 \%$ respectively. These resulted respectively in void content reduction percentages of 0.58 and 0.98 (with a mean of $0.78 \%$ ) for a unit replacement of SDA with GWP. Similarly, the addition of $10 \%$ GWP as a ternary cement resulted in void content reductions of 8.0 and $9.8 \%$ at the total replacement levels of 20 and $30 \%$ respectively. These also resulted respectively in void content reduction percentages of 0.80 and 0.98 (with a mean of $0.89 \%$ ) for a unit replacement of SDA with GWP. Hence, combining the two total replacement levels, a unit replacement of SDA with GWP resulted in a void content reduction of $0.78-0.89 \%$ (with an average of $0.84 \%$ ).

Table 3: Analysis of 28-Day void content and ISAT-10 of concretes

\begin{tabular}{|c|c|c|c|c|c|c|c|}
\hline \multirow[b]{2}{*}{ Mix } & \multirow[b]{2}{*}{$\mathrm{W} / \mathrm{C}$} & \multicolumn{3}{|c|}{ 28-Day void content } & \multicolumn{3}{|c|}{ 28-Day ISAT- 10} \\
\hline & & $\begin{array}{c}\text { Void } \\
\text { content, \% }\end{array}$ & $\begin{array}{l}\text { VCF } \\
\text { a), \% }\end{array}$ & $\begin{array}{c}\text { Average } \\
\text { VCF, } \\
\%\end{array}$ & $\begin{array}{l}\text { ISAT-10 } \\
\times 10^{-2} \\
\mathrm{ml} / \mathrm{m}^{2} \mathrm{~s}^{-1}\end{array}$ & $\begin{array}{c}\text { ISAT-10 } \\
\text { factor }{ }^{b)}, \\
\%\end{array}$ & $\begin{array}{c}\text { Average } \\
\text { ISAT-10 factor, } \\
\%\end{array}$ \\
\hline \multirow{3}{*}{$100 \mathrm{PC}$} & 0.35 & 10.30 & 100 & \multirow{3}{*}{100} & 31.5 & 100 & \multirow{3}{*}{100} \\
\hline & 0.50 & 11.82 & 100 & & 40.7 & 100 & \\
\hline & 0.65 & 14.15 & 100 & & 56.4 & 100 & \\
\hline $80 \mathrm{PC}$ & 0.35 & 12.16 & 118.0 & \multirow{3}{*}{118.0} & 37.4 & 118.7 & \multirow{3}{*}{118.7} \\
\hline \multirow[t]{2}{*}{$+20 \mathrm{SDA}$} & 0.50 & 13.96 & 118.1 & & 48.1 & 118.2 & \\
\hline & 0.65 & 16.70 & 118.0 & & 67.2 & 119.2 & \\
\hline $80 \mathrm{PC}$ & 0.35 & 11.85 & 115.1 & \multirow{3}{*}{115.1} & 36.5 & 115.9 & \multirow{3}{*}{115.0} \\
\hline$+15 \mathrm{SDA}$ & 0.50 & 13.59 & 115.0 & & 46.5 & 114.3 & \\
\hline$+5 \mathrm{GWP}$ & 0.65 & 16.28 & 115.1 & & 64.7 & 114.7 & \\
\hline $80 \mathrm{PC}$ & 0.35 & 11.35 & 110.2 & \multirow{3}{*}{110.0} & 34.9 & 110.8 & \multirow{3}{*}{110.5} \\
\hline$+10 \mathrm{SDA}$ & 0.50 & 12.98 & 109.8 & & 44.8 & 110.1 & \\
\hline$+10 \mathrm{GWP}$ & 0.65 & 15.56 & 110.0 & & 62.3 & 110.5 & \\
\hline $70 \mathrm{PC}$ & 0.35 & 13.40 & 130.1 & \multirow{3}{*}{130.1} & 41.5 & 131.8 & \multirow{3}{*}{132.3} \\
\hline \multirow[t]{2}{*}{$+30 \mathrm{SDA}$} & 0.50 & 15.38 & 130.1 & & 54.0 & 132.7 & \\
\hline & 0.65 & 18.42 & 130.2 & & 74.7 & 132.5 & \\
\hline $70 \mathrm{PC}$ & 0.35 & 12.91 & 125.3 & \multirow{3}{*}{125.2} & 39.8 & 126.4 & \multirow{3}{*}{126.5} \\
\hline$+25 \mathrm{SDA}$ & 0.50 & 14.80 & 125.2 & & 51.5 & 126.5 & \\
\hline$+5 \mathrm{GWP}$ & 0.65 & 17.72 & 125.2 & & 71.4 & 126.6 & \\
\hline $70 \mathrm{PC}$ & 0.35 & 12.38 & 120.2 & \multirow{3}{*}{120.2} & 38.2 & 121.3 & \multirow{3}{*}{122.0} \\
\hline$+20 \mathrm{SDA}$ & 0.50 & 14.21 & 120.2 & & 49.8 & 122.4 & \\
\hline$+10 \mathrm{GWP}$ & 0.65 & 17.01 & 120.2 & & 68.9 & 122.2 & \\
\hline
\end{tabular}

a) Void content factor (VCF)- Ratio of void content of concrete to that of 100PC concrete

b) ISAT-10 factor- Ratio of ISAT-10 with respect to the $100 \mathrm{PC}$ concrete

The 28-day ISAT-10 of concrete increased respectively by 18.7 and $32.3 \%$ at 20 and $30 \%$ contents of SDA resulting in percentages of increase in ISAT-10 of 0.94 and 1.08 respectively (with a mean of $1.01 \%$ ) for a unit replacement of PC with SDA. With the addition of $5 \% \mathrm{GWP}$, as a ternary cement component, the 28-day ISAT10 reduced by 3.7 and $5.8 \%$ at the total replacement levels of 20 and $30 \%$ respectively. These resulted respectively in ISAT-10 reduction percentages of 0.74 and 1.16 (with a mean of $0.95 \%$ ) for a unit replacement of SDA with GWP. Similarly, the addition of $10 \%$ GWP as a ternary cement resulted in ISAT-10 reductions of 8.2 and $10.3 \%$ at the total replacement levels of 20 and $30 \%$ respectively. These also resulted respectively in ISAT10 reduction percentages of 0.82 and 1.03 (with a mean of $0.93 \%$ ) for a unit replacement of SDA with GWP. Hence, combining the two total replacement levels, a unit replacement of SDA with GWP resulted in ISAT-10 reduction of $0.93-0.95 \%$ (with an average of $0.94 \%$ ). Therefore, GWP as a ternary cement component could be used to reduce the void content and initial surface absorption and increase the permeation resistance and durability of SDA blended cement concrete.

\subsection{Void Content and initial Surface Absorption of Concrete at Equal 28-Day Strengths}

The specification of structural concrete is based on the 28-day strengths. Hence, in order to assess the permeation resistance of the concretes at equal 28-day compressive strengths, the 28-day compressive strengths in Table 2 and the 28-day void content and ISAT-10 values in Table 3 have been interpolated over the water/cement ratios. Hence, Table 4 presents the water/cement ratios at which the 28 -day strengths of $35-40 \mathrm{~N} / \mathrm{mm}^{2}$ were achieved by the blended cement concretes and the corresponding void content and ISAT-10 values at these strengths. Table 4 
reveals that equal strengths with $100 \mathrm{PC}$ concrete were attained by the blended cement concretes at lower water/cement ratios. The implication of this is that higher cement content would be required by the blended cement concretes to achieve equal strengths with the conventional 100PC concrete. Comparatively, at equal total replacement levels, the SDA binary cement concretes would require lower water/cement ratios than the ternary cement concretes to achieve equal strengths with the 100PC concrete. Also, the water/cement ratios required to achieve equal strengths with the 100PC concrete decreased with increase in the content of SDA as a binary cement component and increased with increase in the content of GWP as a ternary cement component. The implication of this is that more cement content will be required by the SDA binary cement concretes than the corresponding GWP ternary cement concretes at equal strengths. This result is supported by Folagbade \& Newlands (2014b) and Folagbade \& Aluko (2019). The foregoing also supports the propensity of GWP to support compressive strength development than SDA.

Table 4: Void content and ISAT-10 at equal 28-day strengths of concrete

\begin{tabular}{|c|c|c|c|c|c|c|c|c|c|}
\hline \multirow{3}{*}{ Mix combination } & \multicolumn{9}{|c|}{ Compressive strength at 28 days } \\
\hline & \multicolumn{3}{|c|}{$35 \mathrm{~N} / \mathrm{mm}^{2}$} & \multicolumn{3}{|c|}{$37 \mathrm{~N} / \mathrm{mm}^{2}$} & \multicolumn{3}{|c|}{$40 \mathrm{~N} / \mathrm{mm}^{2}$} \\
\hline & $\mathrm{w} / \mathrm{c}$ & $\mathrm{VC}^{\text {a) }}$ & ISAT $^{\text {b) }}$ & $\mathrm{w} / \mathrm{c}$ & $\mathrm{VC}^{\text {a) }}$ & ISAT $^{\text {b) }}$ & $\mathrm{w} / \mathrm{c}$ & $\mathrm{VC}^{\text {a) }}$ & ISAT $^{\text {b) }}$ \\
\hline $100 \mathrm{PC}$ & $*$ & $*$ & $*$ & 0.65 & 14.15 & 56.4 & 0.52 & 12.08 & 42.4 \\
\hline $80 \mathrm{P}+20 \mathrm{SDA}$ & 0.43 & 13.00 & 42.1 & 0.40 & 12.66 & 40.0 & 0.35 & 12.16 & 37.4 \\
\hline $80 \mathrm{PC}+15 \mathrm{SDA}+5 \mathrm{GWP}$ & 0.52 & 13.89 & 48.5 & 0.47 & 13.17 & 43.8 & 0.42 & 12.54 & 40.2 \\
\hline $80 \mathrm{PC}+10 \mathrm{SDA}+10 \mathrm{GWP}$ & 0.61 & 14.78 & 56.9 & 0.53 & 13.42 & 47.7 & 0.46 & 12.45 & 41.4 \\
\hline $70 \mathrm{PC}+30 \mathrm{SDA}$ & 0.35 & 13.40 & 41.5 & $\mathrm{x}$ & $\mathrm{x}$ & $\mathrm{x}$ & $\mathrm{x}$ & $\mathrm{x}$ & $\mathrm{x}$ \\
\hline $70 \mathrm{PC}+25 \mathrm{SDA}+5 \mathrm{GWP}$ & 0.41 & 13.54 & 43.5 & 0.38 & 13.21 & 41.5 & $\mathrm{x}$ & $\mathrm{x}$ & $\mathrm{x}$ \\
\hline 70PC+20SDA+10GWP & 0.48 & 13.91 & 47.8 & 0.44 & 13.36 & 44.3 & 0.39 & 12.77 & 40.6 \\
\hline
\end{tabular}

a) Void content $(\%)$

b) ISAT-10 × 10-2, $\left(\mathrm{ml} / \mathrm{m}^{2} \mathrm{~s}^{-1}\right)$

* The required water/cement ratio is higher than 0.65

$\mathrm{x}$ The required water/cement ratio is lower than 0.35

Table 4 shows that void content and ISAT-10 of concrete reduced with increase in compressive strength. Also, all the binary and ternary cement concretes at up to $30 \%$ total contents of SDA and GWP have lower void contents and ISAT-10 values and would therefore have higher resistance to permeation than the 100PC concrete at equal strengths. This observation is supported by Dhir \& Byars (1991), Dias et al. (2003), Folagbade (2016, 2017) and Folagbade \& Aluko (2019) which show that blended cement concretes have the tendency to perform better than the conventional Portland cement concrete at equal strengths. Furthermore, Table 4 shows that, at equal strengths, void content and ISAT-10 of concrete reduced with increase in SDA content as a binary cement component and increased with increase in GWP content as a ternary cement component. This implies that, at equal strengths, the addition of GWP as a ternary cement component would result in better strength development but not better resistance to permeation than SDA. Hence, at equal strengths, SDA would have more beneficial effect on durability than GWP when the design criterion is solely durability. However, since lower water/cement ratios and hence higher contents of cement will be required by the binary than the ternary cement concretes, the final choice will depend on the economic implication (material costs) and environmental implication (embodied carbon-dioxide contents) of the concretes at equal strengths (Folagbade, 2014; Folagbade \& Newlands, 2014a,b) or at equal performance levels.

\subsection{Blended Cement Concrete at Equal Performance Level}

Table 5 compares the performance of the blended cement concretes by determining, within the limit of the study, the water/cement ratios at which the concrete mixes achieved equal performance with the 80PC+20SDA concrete (void content of $13.0 \%$ and ISAT-10 of $42.1 \times 10^{-2} \mathrm{ml} / \mathrm{m}^{2} \mathrm{~s}^{-1}$ ). The Table shows that at the two total replacement levels (20 and 30\%), the ternary cement concretes require higher water/cement ratios than the binary cement concretes to achieve equal performance level of $13 \%$ void content and $42.1 \times 10^{-2} \mathrm{ml}^{2} \mathrm{~m}^{2} \mathrm{~s}^{-1}$ ISAT-10. Hence, assuming almost equal cost and embodied carbon dioxide contents for SDA and GWP, the binary cement concretes will require higher cement contents and attract higher cost and embodied carbondioxide contents than the ternary cement concretes. Hence, it could be concluded that the addition of GWP, as a ternary cement component would improve the strength and permeation resistance of SDA binary cement concrete. 
Table 5: Blended cement concretes at equal 28-day void content and ISAT-10 performance

\begin{tabular}{lcc}
\hline \multirow{2}{*}{ Mix combination } & \multicolumn{2}{c}{ Water/Cement Ratio } \\
\cline { 2 - 3 } & Void Content $=13 \%$ & ISAT-10 $=42.1 \times 10^{-2} \mathrm{ml}^{\prime} \mathrm{m}^{2} \mathrm{~s}^{-1}$ \\
\hline 80P+20SDA & 0.43 & 0.43 \\
80PC+15SDA+5GWP & 0.46 & 0.44 \\
80PC+10SDA+10GWP & 0.50 & 0.46 \\
\hline 70PC+30SDA & $\mathrm{x}$ & 0.36 \\
70PC+25SDA+5GWP & 0.36 & 0.39 \\
$70 \mathrm{PC}+20 \mathrm{SDA}+10 \mathrm{GWP}$ & 0.41 & 0.41 \\
\hline
\end{tabular}

${ }^{\mathrm{x}}$ Water/Cement ratio is lower than 0.35

\section{Conclusion}

The compressive strength development, void content and initial surface absorption of concretes containing SDA and GWP as partial replacements, of up to a total content of $30 \%$, for PC have been investigated. The following conclusions have been drawn from the study.

- Compressive strength increased with increase in curing age and reduced with increase in water/cement ratio. On the other hand, while void content and initial surface absorption reduced with increase in curing age and compressive strength, they increased with increase in water/cement ratio.

- At same water/cement ratios, compressive strength reduced and void content and initial surface absorption increased with increase in the content of SDA as a binary cement component. On the other hand, compressive strength increased and void content and initial surface absorption reduced with increasing content of GWP as a ternary cement component.

- All the binary and ternary blended cement concretes, at replacement levels up to $30 \%$, achieved equal strengths with the conventional PC concrete at lower water/cement ratios. However, at equal total replacement levels, SDA binary cement concretes would require lower water/cement ratios and therefore more cement contents than the ternary cement concretes to achieve equal strengths.

- Also, at equal strengths, all the binary and ternary blended cement concretes have lower void content and ISAT-10 values and hence higher permeation resistance than the $100 \%$ PC concrete. Furthermore, GWP has better propensity to improve permeation resistance than SDA at equal performance levels.

Hence, for better strength and permeation resistance, the addition of GWP as a ternary cement component to the binary combination of PC and SDA content of concrete would permit the use of SDA content higher than $20 \%$ in concrete and result in structural concrete with higher permeation resistance than the $100 \% \mathrm{PC}$ concrete.

\section{References}

Adesanya, D. A., \& Raheem, A. A. (2009). A study of the workability and compressive strength characteristics of corncob ash blended cement concrete. Construction and Building Materials, 23, 311-317.

Adesanya, D. A., \& Raheem, A. A. (2010). A study of the permeability and acid attack of corncob ash blended cements. Construction and Building Materials, 24, 403-409.

Akinwumi, I. I., \& Aidomojie, O. I. (2015). Effect of corncob ash on the geotechnical properties of lateritic soil stabilized with Portland cement. International Journal of Geomatics and Geosciences, 5(3), 375-392.

ASTM C642 (2006). Standard test method for density, absorption, and voids in hardened concrete. Pennsylvania: American Society for Testing and Materials International.

Bai, J., Sabir, B. B., Wild, S., \& Kinuthia, J. M. (2000). Strength development in concrete incorporating PFA and metakaolin. Magazine of Concrete Research, 52(3), 153-162.

BS EN 197- 1 (2000). Cement- Part 1: Composition, specifications and conformity criteria for common cements. London: British Standards Institution.

BS EN 206- 1 (2000). Concrete- Part 1: Specification, performance, production and conformity. London: British Standards Institution.

BS EN 934-2 (2009). Admixtures for concrete, mortar and grout-Part 2: Concrete admixtures- Definitions, requirements, conformity, marking and labelling. London: British Standards Institution.

BS 1881- 208 (1996). Testing concrete- Part 208: Recommendations for the determination of the initial surface absorption of concrete. London: British Standards Institution.

BS 8500- 1 (2006). Concrete- Complementary British Standard to BS EN 206- 1- Part 1: Method of specifying and guidance for the specifier. London: British Standards Institution.

BS 8500- 2 (2006). Concrete- Complementary British Standard to BS EN 206- 1- Part 2: Specification for constituent materials and concrete. London: British Standards Institution.

BS EN 12390- 2 (2000). Testing hardened concrete- Part 2: Making and curing specimens for strength tests. London: British Standards Institution. 
BS EN 12390- 3 (2002). Testing hardened concrete- Part 3: Compressive strength of test specimens. London: British Standards Institution.

Coutinho, J. S. (2003). The combined benefits of CPF and RHA in improving the durability of concrete structures. Cement and Concrete Composites, 25, 51-59.

Dhir, R. K., \& Byars, E. A. (1991). PFA concrete: Near surface absorption properties. Magazine of Concrete Research, 43 (157), 219-232.

Dias, W. P. S., Nanayakkara, S. M. A., \& Ekneligoda, T. C. (2003). Performance of concrete mixes with OPCPFA Blends. Magazine of Concrete Research, 55 (2), 161-170.

Elinwa, A. U., \& Ejeh, S. P. (2004). Effects of incorporation of sawdust waste incineration fly ash in cement pastes and mortars. Journal of Asian Architecture and Building Engineering, 3(1), 1-7.

Elinwa, A. U., Ejeh, S. P., \& Akpabio, I. O. (2005). Using metakaolin to improve sawdust ash concrete. Concrete International, 27(11), 49-52.

Folagbade, S. O. (2014). Influence of fly ash and silica fume on the compressive strength development of Portland cement concrete. Journal of Environmental Design and Management, 6(1 \& 2), 36-50.

Folagbade, S. O. (2016). Absorption characteristics of cement combination concrete containing Portland cement, fly ash and metakaolin. Civil Engineering Dimension, 18(1), 57-64.

Folagbade, S. O. (2017). Early-age performance of cement combination concrete. Civil Engineering Dimension, 19(1), 14-20.

Folagbade, S. O. (2018). Effect of sawdust ash on the compressive strength and sorptivity of laterised concrete. Civil and Environmental Research, 10(10), 5-14.

Folagbade, S. O., \& Aluko, O. (2019). Permeation resistance of sawdust ash blended cement laterized concrete. Civil Engineering Dimension, 21(2), 76-83.

Folagbade, S. O., \& Newlands M. (2014a). Compressive strength development of blended cement concretes containing Portland cement, fly ash and metakaolin. The Indian Concrete Journal, 88(9), 20-29.

Folagbade, S. O., \& Newlands, M. D. (2014b). Suitability of cement combinations for carbonation resistance of structural concrete. Journal of Engineering, Design and Technology, 12(4), 423-439.

Hassan, K. E., Cabrera, J. G., \& Maliehe, R. S. (2000). The effect of mineral admixtures on the properties of high-performance concrete. Cement and Concrete Composites, 22 (4), 267-271.

Ke, G., Li, W., Li, R., Li, Y., \& Wang, G. (2018). Mitigation effect of waste glass powders on alkali-silica reaction (ASR) expansion in cementitious composite. International Journal of Concrete Structures and Materials, 12(67).

Khatib, J. M., Negim, E. M., Sohl, H. S., \& Chileshe, N. (2012). Glass powder utilisation in concrete production. European Journal of Applied Sciences, 4(4), 173-176.

Maraghechi, H., Maragechi, M., \& Rajabipour, F. (2014). Pozzolanic reactivity of recycled glass powder at elevated temperatures: Reaction stoichiometry, reaction products and effect of alkali activation. Cement and Concrete Composites, 53, 105-114.

Nehdi, M., Duquette, J., \& Damatty, A. (2003). Performance of rice husk ash produced using a new technology as a mineral admixture in concrete. Cement and Concrete Research, 33(8), 1203-1210.

Obilade, I. O. (2014). Use of sawdust ash as a partial replacement for cement in concrete. International Journal of Engineering Science Invention, 3(8), 36-40.

Ogunbode, E. B., \& Akanmu, W. P. (2012). Turning waste to wealth: Potential of laterized concrete using cassava peels ash (CPA) blended cement. International Journal of Engineering Research \& Technology, $1(3), 1-12$.

Oluoti, K., Megwai, G., Petterson, A., \& Richards, T. (2014). Nigerian wood waste: A dependable and renewable fuel option for power production. World Journal of Engineering and Technology, 2, 234-248.

Poon, C. S., Kou, S. C., \& Lam, L. (2006). Compressive strength, chloride diffusivity and pore structure of high performance metakaolin and silica fume concrete. Construction and Building Materials, 20, 858-865.

Radlinski, M., \& Olek, J. (2012). Investigation into the synergistic effects in ternary cementitious systems containing Portland cement, fly ash and silica fume. Cement and Concrete Composites, 34(4), 451-459.

Raheem, A. A., Adedokun, S. I., Ajayi, B. R., Adedoyin, O. A., \& Adegboyega, B. O. (2017). Application of sawdust ash as partial replacement for cement in the production of interlocking paving stones. International Journal of Sustainable Construction Engineering and Technology, 8(1), 1-11.

Rashed, A. M. (2014). Recycled waste glass as fine aggregate replacement in cementitious materials based on Portland cement. Construction and Building Materials, 72, 340-357.

Sadiqul Islam, G. M., Rahman, M. H., \& Kazi, N. (2017). Waste glass powder as partial replacement of cement for sustainable concrete practice. International Journal of Sustainable Built Environment, 6, 37-44.

Shayan, A., \& Xu, A. (2006). Performance of glass powder as a pozzolanic material in concrete: A field trial on concrete slabs. Cement and Concrete Research, 36(3), 457-468.

Teychenne, D. C., Franklin, R. E., \& Erntroy, H. C. (1997). Design of normal concrete mixes (2nd ed.) amended 
by B. K. Marsh. Watford: Building Research Establishment.

Thomas, M. D. A, Shehata, M. H, Shashiprakash, S. G., Hopkins, D. S., \& Cail, K. (1999). Use of ternary cementitious systems containing silica fume and fly ash in concrete. Cement and Concrete Research, 29(8), 1207-1214.

Udoeyo, F. F., \& Dashibil, P. U. (2002). Sawdust ash as a concrete material. Journal of Materials in Civil Engineering, 14(2), 173-176.

Wild, S., Khatib, J. M., \& Jones, A. (1996). Relative strength pozzolanic activity and cement hydration in superplasticised metakaolin concrete. Cement and Concrete Research, 26(10), 1537-1544.

Zhang, M. H., \& Malhotra, V. M. (1996). High performance concrete incorporating RHA as a supplementary cementing material. ACI Material Journal, 93(6), 629-639. 